\title{
ASSESSMENT OF TRYPTOPHOL GENOTOXICITY IN FOUR CELL LINES IN VITRO: A PILOT STUDY WITH ALKALINE COMET ASSAY
}

\author{
Ivan KOSALEC ${ }^{1}$, Snježana RAMIĆ ${ }^{2}$, Dubravko JELIĆ ${ }^{3 *}$, Roberto ANTOLOVIĆ ${ }^{4}$, \\ Stjepan PEPELJNJAK ${ }^{1}$, and Nevenka KOPJAR ${ }^{5}$ \\ Department of Microbiology, Faculty of Pharmacy and Biochemistry University of Zagreb ${ }^{1}$, University Hospital \\ for Tumours', GlaxoSmithKline Research Centre Ltd. ${ }^{3}$, Zagreb, Croatia; School of Medicine, University of Rijeka ${ }^{4}$, \\ Rijeka, Croatia; Institute for Medical Research and Occupational Health ${ }^{5}$, Zagreb, Croatia \\ Received in January 2011 \\ CrossChecked in January 2011 \\ Accepted in February 2011
}

\begin{abstract}
Tryptophol is an aromatic alcohol and secondary metabolite of the opportunistic fungus Candida albicans. Although its toxicity profile at cell level has been poorly investigated, recent data point to cytotoxic, cytostatic, and genotoxic effects in lymphocytes and the induction of apoptosis in leukaemic blood monocytes. In this pilot study we evaluated the genotoxicity of tryptophol in vitro on four permanent cell lines of animal and human origin: ovary cells, alveolar epithelium, liver cells, and blood monocytes using the alkaline comet assay. We selected cells that might be principal targets of tryptophol and other low-molecular geno(toxins) secreted by Candida albicans during host invasion. Our results suggest that tryptophol applied in vitro at $2 \mathrm{mmol} \mathrm{L}^{-1}$ for $24 \mathrm{~h}$ damages DNA in HepG2, A549 and THP-1 cells, obviously due to bioactivation and/or decomposition of the parent compound, which results in the formation of more genotoxic compound(s) and production of reactive species that additionally damage DNA. On the other hand, notably lower levels of primary DNA damage were recorded in $\mathrm{CHO}$ cells, which lack metabolic activity. Future studies with tryptophol should look further into mechanisms involved in its toxic action and should focus on other cell types prone to infection with Candida spp. such as vaginal epithelial cells or keratinocytes of human origin.
\end{abstract}

KEY WORDS: aromatic alcohol, Candida albicans, DNA damage, permanent cell lines, secondary metabolite

Microorganisms produce various secondary metabolites, low-molecular-weight compounds that are not essential for their normal development, but play an important role in cell defence and survivability and also mediate cell-to-cell communication. The last, also termed as "quorum sensing" is a well-known cell-signalling mechanism in bacteria (1). Candida albicans is the first simple eukaryotic microorganism described to possess the quorum-sensing ability (2). Its main quorum-sensing molecules are aromatic alcohols tyrosol, farnesol, tryptophol, and 2phenylethanol (2-4).
Although C. albicans is one of the most important human pathogens, the mechanisms of infection with this opportunistic fungus are still not fully elucidated. The members of genus Candida normally exist as a commensal microflora on the skin, mucosal surfaces, and in the gastrointestinal tract of healthy humans and animals (5). In some conditions, however, they become harmful and invade their host. Recent findings suggest that the virulence of $C$. albicans is linked to

* Present address: Galapagos Research Centre Ltd., Zagreb, Croatia 
its ability for phenotypic switching from yeast-form to filamentous growth (6). Oval yeast cells are more prevalent in commensal interactions, while in opportunistic infections filamentous forms prevail. Such infections range from localised mycoses (superficial and deep-seated ones) to serious systemic diseases that may lead to death (mainly in immunocompromised hosts) $(5,7)$.

The morphological transition of C. albicans is influenced by numerous stimuli such as increased $\mathrm{pH}$ and temperature, low availability of nutrients, low cell density, and the presence of certain compounds that promote or block filamentation (7-9). Aromatic alcohol tyrosol, for instance, stimulates morphological transition of $C$. albicans from yeasts to hyphae (3), while farnesol, farnesoic acid, tryptophol, and 2phenylethanol mostly repress hyphal development (2, 4, 9-11).

The role of tryptophol (3-indole-ethanol) in the quorum sensing of $C$. albicans was established in 2000 's (7). This aromatic alcohol (Figure 1) is formed as the end product of tryptophan catabolism in certain

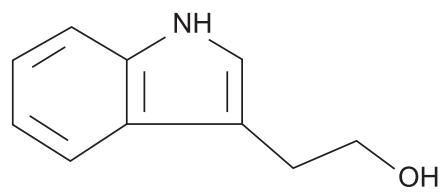

Figure 1 Structural formula of tryptophol

bacteria, yeasts, and fungi (7, 12-14). In higher plants, tryptophol is an endogenous constituent and growth regulator (15). It is also a product of tryptophan metabolism by Trypanosoma brucei and is involved in the pathophysiology of sleeping sickness caused by these blood parasites $(16,17)$. Tryptophol has also been found in the bloodstream of patients with chronic trypanosomiasis (18).

The toxicity profile of tryptophol at the cell level is not complete. Tanaka et al. (19) observed mutagenic effects of 1-nitrosotryptophol and 6-nitrosotryptophol in Ames' Salmonella typhimurium tester strains. Others have found that it induces apoptosis in the human leukemic cell line U937 (20-22). In the dose range $(0.25$ to 2.00$) \mathrm{mmol} \mathrm{L}^{-1}$ tryptophol induced cytotoxic and cytostatic effects and caused DNA breaks in human lymphocytes (23), but was not mutagenic to Ames' Salmonella TA 98 and TA 100 (24).

Current evidence on tryptophol toxicity is obviously not sufficient for human risk assessment. Considering that infection with C. albicans - confirmed as tryptophol producer $(7,14)$ - may be localised but can also become a systemic disease, various organs, tissues, and cell types in the host invaded by $C$. albicans are potential targets of tryptophol toxicity. It is also reasonable to anticipate that different cells would express different DNA sensitivity to tryptophol, but we have not got this information as yet. Assuming different exposure scenarios, in this pilot study we tried to establish the genotoxicity of tryptophol on four cell lines of animal and human origin: ovary cells, alveolar epithelium, liver cells, and blood monocytes. The level of primary DNA damage was evaluated using the alkaline comet assay. Regardless of the simple design, we expect that results of this study might help to better understand how important tryptophol is for the pathogenic action of Candida spp.

\section{MATERIAL AND METHODS}

\section{Cell lines}

We used commercially available cell lines (strain number in brackets): A549 (human Caucasian lung carcinoma, ECACC 86012804), CHO (Chinese hamster ovary cells, ECACC 85050302), HepG2 (human Caucasian hepatocyte carcinoma, ECACC 85011430), and THP-1 (human monocyte leukemia, ECACC 88081201) that were purchased from the European collection of cell lines (ECACC, United Kingdom).

\section{Chemicals}

Tryptophol (3-indole-ethanol, CAS No. 526-55-6; MW 161.20) was purchased from Sigma Chemical Co. (St. Louis, MO, USA).

If not otherwise specified, other chemicals and reagents were also purchased from the same supplier.

\section{Culture conditions and toxicity testing}

All cells were cultured in Dulbecco's modified Eagle's Medium supplemented with foetal calf serum $(10 \% \mathrm{~V} / \mathrm{V})$, penicillin $\left(100 \mathrm{U} \mathrm{mL}^{-1}\right)$, streptomycin $\left(100 \mu \mathrm{g} \mathrm{mL}^{-1}\right)$, and amphotericin B $\left(0.25 \mu \mathrm{g} \mathrm{mL}^{-1}\right)$ at $37^{\circ} \mathrm{C}$ in atmosphere humified with $5 \% \mathrm{CO}_{2}$.

One day prior to experiments, the cells were subcultured in 96-well microtitre plates. Each well contained from 50,000 to 75,000 cells (in the case of THP-1). Cells were treated with tryptophol in the 
concentration of $2.00 \mathrm{mmol} \mathrm{L}^{-1}$. As before use, tryptophol was dissolved in DMSO, this solvent was also added to control cultures. The final concentration of DMSO in the medium did not exceed $1 \%$. Treated cell cultures and controls were incubated at $37^{\circ} \mathrm{C}$ for $24 \mathrm{~h}$. Tested concentration of tryptophol and the exposure period were based on results obtained in previous dose-range studies $(20,23)$.
Each test was repeated four times and data were pooled.

\section{The alkaline single-cell gel electrophoresis (comet assay)}

Immediately after treatment, aliquots of each cell suspension $(\mathrm{V}=40 \mu \mathrm{L})$ were collected with sterile pipette and used for the preparation of agarose

Table 1 Alkaline comet assay findings for A549, Hep G2, THP-1, and CHO cells treated in vitro with tryptophol in the concentration of $2 \mathrm{mmol} \mathrm{L}^{-1}$ for $24 \mathrm{~h}$ and for corresponding controls

\begin{tabular}{|c|c|c|c|c|c|c|c|c|}
\hline \multirow{2}{*}{$\begin{array}{l}\text { Alkaline } \\
\text { comet assay }\end{array}$} & \multicolumn{2}{|c|}{ A549 } & \multicolumn{2}{|c|}{ HepG2 } & \multicolumn{2}{|c|}{ THP-1 } & \multicolumn{2}{|c|}{ CHO } \\
\hline & Tryptophol & Control & Tryptophol & Control & Tryptophol & Control & Tryptophol & Control \\
\hline $\begin{array}{l}\text { Tail length } \\
\text { / } \mu \mathrm{m}\end{array}$ & $17.08 \pm 0.35^{*}$ & $15.08 \pm 0.15$ & $18.80 \pm 0.25^{*}$ & $16.11 \pm 0.13$ & $15.80 \pm 0.38^{*}$ & $13.69 \pm 0.11$ & $14.40 \pm 0.17$ & $14.32 \pm 0.16$ \\
\hline $\begin{array}{l}\text { Tail intensity } \\
\text { / DNA\% }\end{array}$ & $1.27 \pm 0.25^{*}$,\# & $0.49 \pm 0.06$ & $0.95 \pm 0.09 *$,\# & $0.33 \pm 0.04$ & $1.05 \pm 0.34$ & $0.49 \pm 0.06$ & $0.48 \pm 0.08^{*}$ & $0.26 \pm 0.04$ \\
\hline Tail moment & $0.22 \pm 0.05^{*}$ & $0.07 \pm 0.01$ & $0.17 \pm 0.02 *$ & $0.05 \pm 0.01$ & $0.19 \pm 0.07$ & $0.06 \pm 0.01$ & $0.07 \pm 0.01^{*}$ & $0.03 \pm 0.004$ \\
\hline
\end{tabular}

Data are expressed as mean \pm S.E. of 200 comets measured for each sample. Statistical evaluation was performed using the Mann-Whitney U test. Values significantly higher than corresponding control $(P<0.05)$ are marked with an asterisk (*). Intragroup differences were studied only for tail intensity using the one-way ANOVA with post hoc Schéffe test. \# denotes values significantly higher $(P<0.05)$ than for $\mathrm{CHO}$ cells
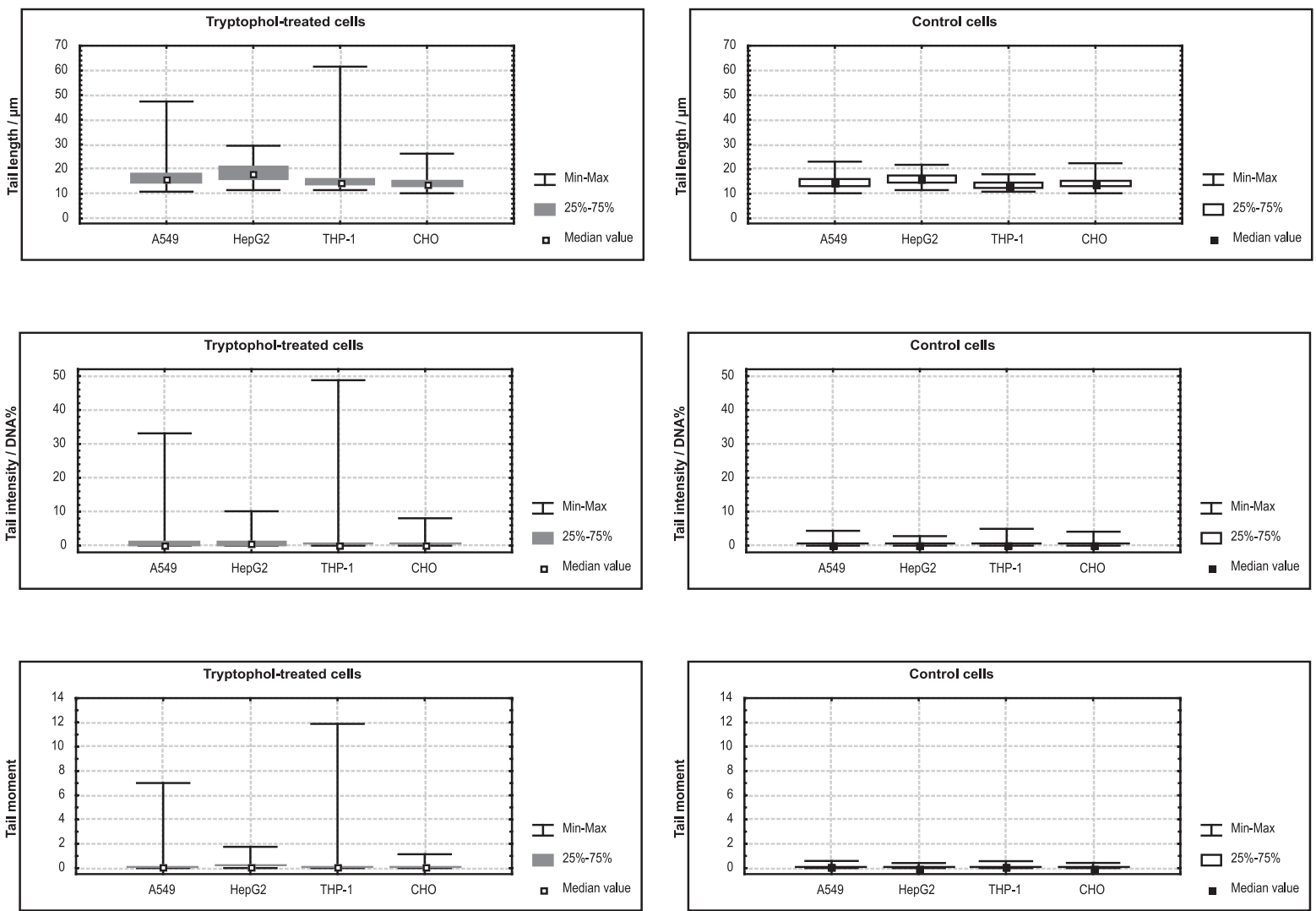

Figure 2 Alkaline comet assay findings for A549, HepG2, THP-1, and CHO cells treated in vitro with tryptophol in the concentration of $2 \mathrm{mmol} \mathrm{L}^{-1}$ for $24 \mathrm{~h}$ and for corresponding controls 


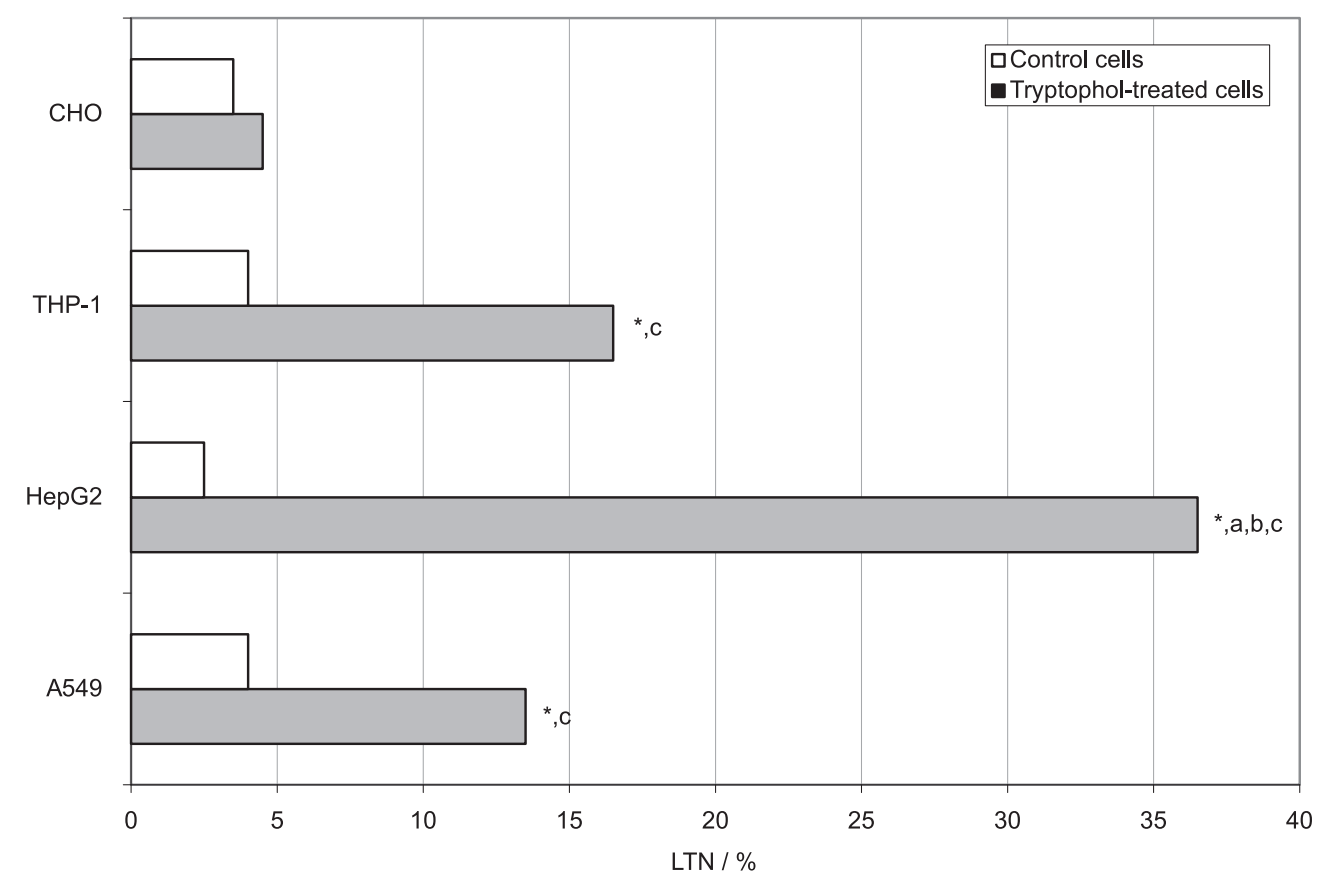

Figure 3 The percentage of long-tailed nuclei (LTN \%) in A549, HepG2, THP-1, and CHO cells treated in vitro with tryptophol in the concentration of $2 \mathrm{mmol}^{-1}$ for $24 \mathrm{~h}$ and in corresponding controls. Inter-group comparisons were performed using the chi-square test. Significantly increased values $(P<0.05)$ are: * vs. control: $a$ - vs. A549 cells; $b$ - vs. THP-1 cells; $c$ - vs. CHO cells.

microgels that were processed following the standard protocol for the alkaline single-cell gel electrophoresis or comet assay (25). Slide preparation and other steps of the comet assay have been described in detail in our earlier paper (23). Microgels were stained with ethidium bromide $\left(20 \mu \mathrm{g} \mathrm{mL}^{-1}\right)$. For each sample, four slides were analysed at 250x magnification under a fluorescence microscope (Leitz, Germany) coupled with a computer-based image analysis system (Comet Assay II, Perceptive Instruments Ltd., United Kingdom). A total of 200 comets $(4 \times 50)$ per sample were measured. They were randomly captured at a constant depth of the gel, avoiding the edges of the gel, occasional dead cells, and superimposed comets. Comet parameters evaluated were tail length, tail intensity (percentage of DNA in the comet tail), and tail moment.

\section{Statistical analyses}

The results are expressed as mean \pm standard error of mean, median, and range of the values measured for comet tail length, tail intensity, and tail moment.

Samples were compared based on logarithmically transformed data using the Mann-Whitney U test and one-way analysis of variance (ANOVA) followed by post-hoc Schéffe test (Statistica 9.0; StatSoft, USA).

For each control sample we also calculated the cut-off value ( $95^{\text {th }}$ percentile) of the tail length. Comets with tail lengths below the cut-off values were classified as "undamaged" and those with higher values as long-tailed nuclei (LTN) (26). The percentage of LTN (LTN \%) was calculated for each sample. Statistical significance of differences in LTN \% between tryptophol-treated and control samples was evaluated using the chi-square test (27). Statistical decisions were made at a significance level of $\mathrm{P}<0.05$.

\section{RESULTS}

Comet assay parameters measured in control samples indicated low level of primary DNA damage in all four cell types (Table 1, Figure 2). The cut-off values for tail length were $19.23 \mu \mathrm{m}$ for A549 and HepG2 cells, $18.59 \mu \mathrm{m}$ for $\mathrm{CHO}$, and $16.67 \mu \mathrm{m}$ for THP-1 cells. We found that control HepG2 cells had the lowest level of spontaneous DNA damage in this experiment with only $2.5 \%$ of LTN (Figure 3 ). Differences in LTN \% between the four cell types were not statistically significant.

Twenty-four-hour incubation with tryptophol resulted in increased DNA damage in all treated cells (Figure 2). Mean tail lengths measured in tryptopholtreated A549, HepG2 and THP-1 cells were significantly 
higher ( $\mathrm{P}<0.05$, Mann-Whitney $\mathrm{U}$ test) than in controls. Significantly higher mean tail intensities and tail moments were found in A549, CHO, and $\mathrm{HepG} 2$ cells (Table 1).

Considering that mean values of comet parameters might be affected by a few high scores, we thought that LTN \% is a valuable additional parameter for better evaluation of DNA damage. Our results show that the most susceptible to treatment were human HepG2 cells, with $36.5 \%$ of LTN, followed by THP1, A549, and CHO cells. Statistical significance of these results is explained more in detail in Figure 3.

Since we evaluated DNA damage in different celltypes, which are known to differ in the amount of nuclear DNA, it makes no sense to compare cell types in terms of the tail length and tail moment. However, tail intensities measured in tryptophol-treated samples indicate that $\mathrm{CHO}$ cells had the lowest percentage of DNA in comet tail compared to other cell types. This difference was significant in respect to A549 and HepG2 cells ( $\mathrm{P}<0.01$, ANOVA followed by post-hoc Schéffe test). Other differences between cell types were not statistically significant.

Microscopic analysis of 200 comets revealed two apoptotic nuclei in tryptophol-treated A549 cells and one in THP-1 cells, while none were found in HepG2 and $\mathrm{CHO}$ cells.

\section{DISCUSSION}

The findings of this pilot study have confirmed our working hypothesis that DNA sensitivity to tryptophol varies with cell type. They also indicate that DNA damaging effects of tryptophol are more pronounced in cell types which retain active enzymes responsible for metabolic activation of DNA reactive compounds, confirming our earlier observation (23) that the parent compound, tryptophol, has a lower genotoxic potential than its metabolite(s). In addition, our present results have shown that permanent cell lines of human origin are more susceptible to DNA damage than the animal cell line CHO. As known, inter species variability in toxic and genotoxic response is related to differences in the uptake, accumulation, metabolism, and excretion of a particular compound. Species also differ in their genetic susceptibility, in the amount of alkali-labile sites in the genome, as well as in the efficiency of DNA repair (28). All these factors should be taken into account when interpreting the results of the alkaline comet assay. This versatile method was used here mainly because it is capable of detecting a wide variety of DNA damage in a single cell: DNA singlestrand breaks, double-strand breaks, DNA-DNA/ DNA-protein cross-links, base damage, alkali-labile sites, and sites subjected to DNA repair (29). The method was also recently applied to assess the genotoxicity of indoleacetic acid and 2methylindoleacetic acid, which are structurally related with tryptophol (30).

The toxicity of tryptophol at the cell level has been poorly investigated so far. Three Japanese studies (20-22) reported that tryptophol induced apoptosis in human monoblastic leukemia cells U937. Inagaki et al. (20) observed that $12 \mathrm{~h}$ of exposure to $80 \mu \mathrm{g} \mathrm{mL}^{-1}$ of tryptophol resulted in the apoptosis of U937 cells, but not of human peripheral blood lymphocytes that were studied in parallel. In our previous study on human peripheral lymphocytes in vitro (23) tryptophol was applied in a dose range of ( 0.25 to 2.00$) \mathrm{mmol}$ $\mathrm{L}^{-1}$ (corresponding to $40.3 \mu \mathrm{g} \mathrm{mL}^{-1}$ to $322.4 \mu \mathrm{g} \mathrm{mL}^{-1}$ ) for $24 \mathrm{~h}$, and we observed its dose-dependent cytotoxic, cytostatic and genotoxic effects. In yet another study (31), the MTT colourimetric assay on five cell lines showed that tryptophol half maximal effective concentration $\left(\mathrm{EC}_{50}\right)$ ranged between $2 \mathrm{mmol} \mathrm{L}^{-1}$ in THP-1 cells to $7 \mathrm{mmol} \mathrm{L}^{-1}$ in the animal $\mathrm{CHO}$ cell line. Based on these results, we decided that this pilot study should focus only on tryptophol concentration of $2 \mathrm{mmol} \mathrm{L}^{-1}$, while other relevant concentrations will be tested in future studies.

Based on the types and extent of cytogenetic damage observed earlier in tryptophol-treated lymphocytes (23), we assumed that the culprit for direct DNA lesions could be an aldehyde metabolite. Such scenario is quite possible, as tryptophol is an aromatic alcohol and aldhydes are usually formed as metabolites of other alcohols $(32,33)$. For instance, production of acetaldehyde from ethanol by oral microbes is also observed in vivo and is related to the pathogenesis of oral cancer (34). Reactive aldehydes and other reactive radicals that are formed as a result of oxidative stress might cause DNA lesions, which are detectable with the alkaline comet assay. The results of our present study support this hypothesis, as all tested cells types responded positively to tryptophol treatment, especially the cells with high metabolic potential.

Since we used three human and one animal permanent cell line, a reliable interpretation of the results should include a proper parameter which is not species-dependent. As the amount of DNA in a nucleus 
is species-specific, simple comparisons of comet parameters between human and animal cells are not possible. With LTN, however, we can compare DNA damage between different cell types. Our results show that HepG2 cells, which retain the most of active enzymes found in the liver, were the most susceptible to tryptophol. Previous studies on HepG2 cells indicate that these cells keep many functions of the normal human liver and are metabolically competent to activate different classes of mutagens into biologically active metabolites (35-38). The finding on high susceptibility of HepG2 cells to tryptophol deserves particular attention because of many interactions between tryptophan and alcohol in mammalian liver (39), including its metabolism into tryptophol. In addition, tryptophol is known formed in the liver after treatment with disulfiram (40).

The percentage of LTN in tryptophol-treated THP1 and A549 cells was lower than in HepG2 cells. A549 cells possess enzymes necessary for metabolic activation (41) and have a high level of glutathione (42). We believe that this was crucial for lower LTN \% in A549 than in HepG2 cells. Apparently, A549 cells better counteracted oxidative stress caused by tryptophol treatment than did HepG2. Similar findings on the sensitivity of A549 cells have been reported by Speit and Bonzheim (43), who found that the DNA damaging effect of hyperbaric oxygen, determined using the alkaline comet assay, was more pronounced in V79 than in A549 cells.

THP-1, the third cell type used in this study, are human monocytic leukaemia cells (44) related to U937 cells, which were used to study tryptophol toxicity in the past (20-22). Previous investigations indicate that the capacity to maintain cellular glutathione level was better in THP-1 than in U937 cells (45). THP-1 cells lack CYP1A1 (46) and generally have a very low content of proteins involved in metabolic activation (44). We therefore believe that they could not metabolise tryptophol the way HepG2 and A549 cells did. However, one of their important metabolic traits is a high activity of kinurenine pathway enzymes (47). As tryptophol is an end product of tryptophan catabolism, THP-1 possibly metabolised this compound in a different way than other cell types studied here. Our results, however, also suggest that these cells were able to activate some other mechanisms that led to formation of reactive species able to damage DNA. One of the candidates is myeloperoxidase. This enzyme, abundant in monocytes and other phagocytic leukocytes (48), catalyses the reaction between hydrogen peroxide and chloride ions, which results in the formation of hypochlorous acid (HClO) (49). As a strong oxidant, $\mathrm{HClO}$ may interact with other small molecules by generating various reactive oxygen and nitrogen species (50), which in turn might damage DNA indirectly.

In this study we selected four types of cells that might be principal targets of low-molecular geno(toxins) secreted by Candida albicans during host invasion. These compounds deserve attention, as infections with the Candida species are involved in many of modern medical procedures. Candida spp. are frequently identified as agents of nosocomial pneumonias, vaginal and urinary tract infections, and sepsis. In addition, implanted devices (intravascular, central venous catheter or urinary catheters, prosthetic heart valves, cardiac pacemakers and joint replacements, etc.), are also prone to infection by $C$. albicans (51). In addition, its blastoconidia may enter the bloodstream through epithelial tissues and disseminate across organs (52). All this suggests that low-molecular-weight metabolites have to be considered as possible co-factors in Candida spp. invasiveness. Their role is probably as important as the production of hydrolytic enzymes during invasion and the switch from commensal to pathogenic state.

In conclusion, our results with tryptophol applied in vitro at $2 \mathrm{mmol} \mathrm{L}^{-1}$ for $24 \mathrm{~h}$ point to its DNA damaging potential in HepG2, A549 and THP-1 cells, primarily due to the bioactivation and/or decomposition of the parent compound, which results in the formation of more genotoxic compound(s) and production of reactive species that additionally damage DNA. In contrast, notably lower levels of primary DNA damage were observed in $\mathrm{CHO}$ cells that lack metabolic activity (35). Taken together, our results make a solid frame for designing future studies with tryptophol, whose aim is to further clarify mechanisms involved in its toxic action. Future genotoxic studies need to focus on cell types which have not been investigated here, including vaginal epithelial cells or keratinocytes of human origin. It would also be convenient to investigate which intracellular macromolecules besides DNA are potential and/or preferential targets of tryptophol.

\section{Acknowledgements}

This study was in part supported by the Ministry of Science, Education and Sports of the Republic of Croatia (grants no. 006-0061117-1242 and 0220222148-2137). 


\section{REFERENCES}

1. Dufour N, Rao RP. Secondary metabolites and other small molecules as intercellular pathogenic signals. FEMS Microbiol Lett 2011;314:10-7.

2. Hornby JM, Jensen EC, Lisec AD, Tasto JJ, Jahnke B, Shoemaker R, Dussault P, Nickerson KW. Quorum sensing in the dimorphic fungus Candida albicans is mediated by farnesol. Appl Environ Microbiol 2001;67:2982-92.

3. Chen H, Fujita M, Feng Q, Clardy J, Fink GR. Tyrosol is a quorum sensing molecule in Candida albicans. Proc Natl Acad Sci USA 2004;101:5048-52.

4. Chen H, Fink GR. Feedback control of morphogenesis in fungi by aromatic alcohols. Genes Dev 2006;20:1150-61.

5. Enjalbert B, Whiteway M. Release from quorum-sensing molecules triggers hyphal formation during Candida albicans resumption of growth. Eukaryot Cell 2005;4:1203-10.

6. Lo H-J, Köhler JR, DiDomenico B, Loebenberg D, Cacciapuoti A, Fink GR. Nonfilamentous C. albicans mutants are avirulent. Cell 1997;90:939-49.

7. Ghosh S, Kebaara BW, Atkin AL, Nickerson KW. Regulation of aromatic alcohol production in Candida albicans. Appl Environ Microbiol 2008;74:7211-8.

8. Ernst JF. Transcription factors in Candida albicans environmental control of morphogenesis. Microbiology 2000;146:1763-74.

9. Martins M, Henriques M, Azeredo J, Rocha SM, Coimbra MA, Oliveira R. Morphogenesis control in Candida albicans and Candida dubliniensis through signaling molecules produced by planktonic and biofilm cells. Eukaryot Cell 2007;6:2429-36.

10. Oh K-B, Miyazawa H, Naito T, Matsuoka H. Purification and characterization of an autoregulatory substance capable of regulating the morphological transition in Candida albicans. Proc Natl Acad Sci USA 2001;98:4664-8.

11. Shchepin R, Hornby JM, Burger E, Niessen T, Dussault P, Nickerson KW. Quorum sensing in Candida albicans: probing farnesol's mode of action with 40 natural and synthetic farnesol analogs. Chem Biol 2003;10:743-50.

12. Lingappa BT, Prasad M, Lingappa Y, Hunt DF, Biemann K. Phenethyl alcohol and tryptophol: autoantibiotics produced by the fungus Candida albicans. Science 1969;163:192-4.

13. Sugawara F, Strobel GA. Tryptophol a phytotoxin produced by Drechslera nodulosum. Phytochemistry 1987;26: 1349-51.

14. Kosalec I, Pepeljnjak S, Delaforge M, Puel O, Galtier P. Possible toxicity of clinical isoates of Candida albicans. In: Balenović M, editor. Proceedings of the Third Croatian Congress of Microbiology with International Participation; 4-7 Oct 2004. Poreč, Croatia. Zagreb: Hrvatsko mikrobiološko društvo; 2004. p. 115-6.

15. Laćan G, Magnus V, Šimaga Š, Iskrić S, Hall PJ. Metabolism of tryptophol in higher and lower plants. Plant Physiol 1985;78:447-54.

16. Seed JR, Sechelski J. Tryptophol levels in mice injected with pharmacological doses of tryptophol, and the effect of pyrazole and ethanol on these levels. Life Sci 1977;21: 1603-10.

17. Cornford EM, Crane PD, Braun LD, Bocash WD, Nyerges $\mathrm{AM}$, Oldendorf WH. Reduction in brain glucose utilization rate after tryptophol (3-indole ethanol) treatment. J Neurochem 1981;36:1758-65.
18. Koster RL, Grekoff JK. The physiological, hemolytic and immunosuppressive effects of possible trypanosomal metabolites in white mice. Bios 1981;52:227-36.

19. Tanaka K, McConnell B, Niemezura WP, Mower HF. Characterization and mutagenicity of 1-nitrosotryptophol and 6-nitrotryptophol possible genotoxic substances associated with smoking and alcohol consumption. Cancer Lett 1989;44:109-16.

20. Inagaki S, Morimura S, Shigematsu T, Kida K, Akutagawa H. Apoptosis induction by vinegar produced from boiled extract of black soybeans in human monoblastic leukemia U937 cells: Difference in sensitivity to cell toxicity compared to normal lymphocytes. Food Sci Technol Res 2005;11: 311-7.

21. Inagaki $\mathrm{S}$, Morimura $\mathrm{S}$, Gondo $\mathrm{K}$, Tang $\mathrm{Y}$, Akutagawa $\mathrm{H}$, Kida K. Isolation of tryptophol as an apoptosis-inducing component of vinegar produced brom boiled extract of black soybean in human monoblastic leukemia U937 cells. Biosci Biotechnol Biochem 2007;71:371-9.

22. Inagaki S, Morimura S, Tang $\mathrm{Y}$, Akutagawa H, Kida K. Tryptophol induces death receptor (DR) 5-mediated apoptosis in U937 cells. Biosci Biotechnol Biochem 2007;71:2065-8.

23. Kosalec I, Šafranić A, Pepeljnjak S, Bačun-Družina V, Ramić S, Kopjar N. Genotoxicity of tryptophol in a battery of shortterm assays on human white blood cells in vitro. Basic Clin Pharmacol Toxicol 2008;102:443-52.

24. Kosalec I. Toksinogenost i mehanizmi djelovanja virulentnih čimbenika Candida vrsta [Toxicogenicity and mechanisms of action of virulence factors of Candida species] [PhD thesis]. Zagreb: Faculty of Pharmacy and Biochemistry, University of Zagreb; 2006.

25. Singh NP, McCoy MT, Tice RR, Schneider EL. A simple technique for quantitation of low levels of DNA damage in individual cells. Exp Cell Res 1988;175:184-91.

26. Poli P, Buschini A, Spaggiari A, Rizzoli V, Carlo-Stella C, Rossi C. DNA damage by tobacco smoke and some antiblastic drugs evaluated using the comet assay. Toxicol Lett 1999; 108:267-76

27. Chi-Square, Cramer's V, and Lambda [displayed 20 January 2011]. Available at http://faculty.vassar.edu/lowry/newcs. html.

28. Mitchemmore CL, Chipman JK. DNA strand breakage in aquatic organisms and the potential value of the comet assay in environmental monitoring. Mutat Res 1998;399:135-47.

29. Tice RR, Agurell E, Anderson D. Single cell gel/comet assay: guidelines for in vitro and in vivo genetic toxicology testing. Environ Mol Mutagen 2000;35:206-21.

30. Salopek-Sondi B, Piljac-Žegarac J, Magnus V, Kopjar N. Free radical scavenging activity and DNA damaging potential of auxins IAA and 2-Methyl-IAA evaluated in human neutrophils by the alkaline comet assay. J Biochem Mol Toxicol 2010;24:165-73.

31. Kosalec I, Puel O, Delaforge M, Kopjar N, Antolović R, Jelić D, Matica B, Galtier P, Pepeljnjak S. Isolation and cytotoxicity of low-molecular-weight metabolites of Candida albicans. Front Biosci 2008;13:6893-904.

32. Lieber CS. Cytochrome P-4502E1: its physiological and pathological role. Physiol Rev 1997;77:517-44.

33. Ni R, Leo MA, Zhao J, Lieber CS. Toxicity of $\beta$-carotene and its exacerbation by acetaldehyde in HepG2 cells. Alcohol Alcohol 2001;36:281-5. 
34. Meurman JH, Uittamo J. Oral micro-organisms in the etiology of cancer. Acta Odontol Scand 2008;66:321-6.

35. Darroudi F, Natarajan AT. Metabolic activation of chemicals to mutagenic carcinogens by human hepatoma microsomal extracts in Chinese hamster ovary cells (in vitro). Mutagenesis 1993;8:11-5.

36. Knasmüller S, Parzefall W, Sanyal R, Ecker S, Schwab C, Uhl M, Mersch-Sundermann V, Williamson G, Hietsch G, Langer T, Darroudi F, Natarajan AT. Use of metabolically competent human hepatoma cells for the detection of mutagens and antimutagens. Mutat Res 1998;402:185-202.

37. Uhl M, Helma C, Knasmüller S. Evaluation of the single cell gel electrophoresis assay with human hepatoma (HepG2) cells. Mutat Res 2000;468:213-25.

38. Majer BJ, Mersch-Sundermann V, Darroudi F, Laky B, de Wit K, Knasmüller S. Genotoxic effects of dietary and lifestyle related carcinogens in human derived hepatoma (HepG2, Hep3B) cells. Mutat Res 2004;551:153-66.

39. Badawy AAB, Evans M. Alcohol and tryptophan metabolism. Alcohol Alcohol 1974;9:97-115.

40. Cornford EM, Bocash WD, Braun LD, Crane PD, Oldendorf WH. Rapid distribution of tryptophol (3-indole ethanol) to the brain and other tissues. J Clin Invest 1979;63:1241-8.

41. Foster KA, Oster CG, Mayer MM, Avery ML, Audus KL. Characterization of the A549 cell line as a type II pulmonary epithelial cell model for drug metabolism. Exp Cell Res 1998;243:359-66.

42. Carmichael J, Mitchell JB, Friedman N, Gazdar AF, Russo A. Glutathione and related enzyme activity in human lung cancer cell lines. Br J Cancer 1988;58:437-40.

43. Speit G, Bonzheim I. Genotoxic and protective effects of hyperbaric oxygen in A549 lung cells. Mutagenesis 2003;18:545-8.
44. Chipinda I, Ruwona TB, Templeton SP, Siegel PD. Use of the human monocytic leukemia THP-1 cell line and coincubation with microsomes to identify and differentiate hapten and prohapten sensitizers. Toxicology 2011;280:13543. DOI:10.1016/j.tox.2010.12.004.

45. Baird SK, Reid L, Hampton MB, Gieseg SP. OxLDL induced cell death is inhibited by the macrophage synthesised pterin, 7,8-dihydroneopterin, in U937 cells but not THP-1 cells. Biochim Biophys Acta 2005;1745:361-9.

46. Roggen E, Aufderheide M, Cetin Y, Dearman RJ, Gibbs S, Hermanns I, Kimber I, Regal JF, Rovida C, Warheit DB, Uhlig S, Casati S. The development of novel approaches to the identification of chemical and protein respiratory allergens. Altern Lab Anim 2008;36:591-8.

47. Heyes MP, Chen CY, Major EO, Saito K. Different kynurenine pathway enzymes limit quinolinic acid formation by various human cell types. Biochem J 1997;326:351-6.

48. Weiss SJ, LoBuglio AF, Kessler HB. Oxidative mechanisms of monocyte-mediated cytotoxicity. Proc Natl Acad Sci USA 1980;77:584-7.

49. Nakazato T, Sagawa M, Yamato K, Xian M, Yamamoto T, Suematsu M, Ikeda Y, Kizaki M. Myeloperoxidase is a key regulator of oxidative stress mediated apoptosis in myeloid leukemic cells. Clin Cancer Res 2007;13:5436-45.

50. Byun J, Mueller DM, Fabjan JS, Heinecke JW. Nitrogen dioxide radical generated by the myeloperoxidase-hydrogen peroxide-nitrite system promotes lipid peroxidation of low density lipoprotein. FEBS Lett 1999;455:243-6.

51. Douglas LJ. Candida biofilms and their role in infection. Trends Microbiol 2003;11:30-6.

52. Mavor AL, Thewes S, Hube B. Systemic fungal infections caused by Candida species: Epidemiology, infection process and virulence attributes. Curr Drug Targets 2005;6:863-74. 


\section{Sažetak}

\section{PROCJENA GENOTOKSIČNOSTI TRIPTOFOLA NA RAZLIČITIM STANIČNIM LINIJAMA U UVJETIMA IN VITRO: PRELIMINARNA ISTRAŽIVANJA PRIMJENOM KOMET-TESTA U ALKALNIM UVJETIMA}

Triptofol je aromatski alkohol i sekundarni metabolit oportunističkog mikroorganizma Candida albicans. Premda je njegova toksičnost na razini stanice vrlo slabo istražena, noviji podaci upućuju na citotoksične, citostatske i genotoksične učinke triptofola na ljudskim limfocitima te njegovu sposotnost izazivanja apoptoze u leukemijskim monocitima. Cilj ovog preliminarnog istraživanja bio je primjenom komet-testa procijeniti genotoksičnost triptofola u uvjetima in vitro na četiri vrste trajnih staničnih linija životinjskog i ljudskog podrijetla: stanicama jajnika, alveolarnom epitelu, stanicama jetre i monocitima. Izabrali smo one vrste stanica koje bi mogle biti potencijalne "mete" za djelovanje triptofola i srodnih mu niskomolekularnih geno(toksina) koje Candida albicans izlučuje tijekom infekcije domaćina. Dobiveni rezultati pokazuju da triptofol primijenjen u koncentraciji od $2 \mathrm{mmol} \mathrm{L}^{-1}$ tijekom $24 \mathrm{~h}$ u uvjetima in vitro izaziva oštećenja DNA u HepG2, A549 i THP-1-stanicama, vjerojatno zbog bioaktivacije i/ili razgradnje roditeljske molekule koje dovode do nastanka još genotoksičnijih spojeva i stvaranja reaktivnih radikala koji dodatno oštećuju DNA. Značajno niža razina oštećenja utvrđena je u CHO-stanicama koje nemaju enzime potrebne za metaboličku aktivaciju potencijalno genotoksičnih spojeva. Buduća bi istraživanja trebala bolje razjasniti mehanizme koji su u podlozi toksičnosti triptofola i usredotočiti se na druge vrste stanica osjetljive na infekciju mikroorganizmima iz roda Candida, primjerice vaginalne epitelne stanice ili keratinocite ljudskog podrijetla.

KLJUČNE RIJEČI: aromatski alkohol, Candida albicans, oštećenje DNA, sekundarni metaboliti, trajne stanične linije

\section{CORRESPONDING AUTHOR:}

Ivan Kosalec

Faculty of Pharmacy and Biochemistry

Department of Microbiology

Schrottova 39, HR-10 000 Zagreb, Croatia

E-mail: ikosalec@pharma.hr 